\title{
Prežívanie krízy v rodinách počas pandémie Covid-19 na Slovensku
}

\section{Experience of a Family Crisis during Covid-19 Pandemic in Slovakia}

\section{Eva Rajčániová, Petra Ferenčíková, Robert Tomšik, Alena Kopányiová \\ Výskumný ústav detskej psychológie a patopsychológie, Bratislava}

\begin{abstract}
Abstrakt Nástup pandémie koronavírusu priniesol do života rodín množstvo zmien, ktoré mohli znamenat̉ zvýšenú zátaž. Cielom empirickej štúdie bolo zistit mieru prežívania krízy v slovenských rodinách počas pandémie a skúmat jej dopady na život rodín. Zistóvaná bola tiež súvislost' medzi mierou prežívanej krízy a vybranými sociodemografickými premennými. Dáta boli získané pomocou online dotazníka v období od 14. 4. do 19. 5. 2020 na vzorke 458 slovenských rodičov, prevažne matiek. Prežívanie rodinnej krízy bolo zistované pomocou Krátkej škály rodinného distresu (Weiss \& Lunsky, 2012). Z výsledkov vyplýva, že väčšina slovenských rodín neprežívala v sledovanom období závažnejšiu krí$\mathrm{zu}(\mathrm{M}=2,71 ; \mathrm{SD}=1,32)$ a prípadné problémy dokázali zvládat' vlastným úsilím. Vyššia miera prežívanej krízy bola zistená $\mathrm{v}$ rodinách $\mathrm{s}$ det’mi so špeciálnymi výchovno-vzdelávacími potrebami $(M=3,09 ; S D=1,474)$ a $v$ jednorodičovských rodinách $(M=3,06 ; S D=1,854)$ pomocou Mann-Whithey U test a analýzy rozptylu ANOVA.
\end{abstract}

Klúčové slová Covid-19, kríza, rodinný distres, špeciálne výchovno-vzdelávacie potreby.

Abstract The onset of the coronavirus pandemic brought a number of changes into the lives of families, which could have meant an increased burden for them. Among the pandemic measures that most profoundly affected the families' lives were school closures and social distancing, adopted in Slovakia in March 2020. Especially parents of young children were challenged with having to balance work, childcare, education, and housework. Along with other pressures of the pandemic crisis, this might be a great source of stress for parents and their families. The aim of the empirical study was to explore the crisis experien- 
ce in Slovak families during the pandemic and to examine its effects on family life. The relationships between the experienced family crisis and variables such as region, current working status, household type, number of children, presence of special educational needs in children, and personal experience with coronavirus were also examined. Data were obtained using an online questionnaire in the period from 14 April 2020 to 19 May 2020 on a sample of 458 Slovak parents, mostly mothers, aged 25-62. The Brief Family Distress Scale (Weiss \& Lunsky, 2012) was used as a measure of family crisis. School closure and social distancing measures were in force in Slovakia during the whole period under review. The results show that most Slovak families did not experience a serious crisis and were able to manage any problems within their own efforts. This may be associated with the good epidemic situation in Slovakia in the observed time period. When asked about the specific effects of the pandemic on family life, some parents reported positive effects on family life (for example strengthening relationships with partner or children, more time for family or oneself, slowing down, etc.; approx. $19 \%$ of answers), some did not experience any impact on their lives (approx. $13 \%$ of answers). However, majority of the parents reported negative effects of the pandemic on their life, such as financial difficulties, stress, worries, loss of social contacts, lack of free time, etc... Parents whose relatives or acquaintances were infected with coronavirus reported higher levels of family distress than parents with no personal experience with coronavirus, but the difference was not statistically significant. In line with previous research findings, the regions of the country with the highest levels of perceived distress were not always the ones with the highest incidence of coronavirus cases. Neither the current working status, nor number of children were associated with perceived family distress. Higher levels of distress have been found in families with children with special educational needs and in single-parent families. These two groups have been identified to be at a higher risk of negative impact of the Covid-19 pandemic by research conducted in other countries as well. To conclude, majority of Slovak families have experienced no or only limited levels of distress during the onset of the coronavirus pandemic and they were able to deal with problems if and when they arose. However, families with children with special educational needs and single-parent families should be provided with more support, as they experienced higher levels of family distress.

Keywords Covid-19, crisis, family distress, special educational needs. 


\section{Úvod}

Opatrenia súvisiace so šírením ochorenia Covid-19 od marca 2020 významne pozmenili každodenný obraz života mnohých rodičov a ich detí na Slovensku. Na prežívanie slovenských rodín mohlo mat’ vplyv najmä zatvorenie vzdelávacích inštitúcií v polovici marca 2020 a s tým spojená nutnost’ rodičov ostat’ doma s diet’atom a podiel’at sa na vyučovacom procese. Taktiež boli obmedzené sociálne kontakty a vychádzanie z domácností, čo mohlo negatívne vplývat na psychický stav členov rodiny. Vplyvu pandémie koronavírusu a s ním spojených opatrení na duševné zdravie sa venovalo viacero výskumov z celého sveta (Biroli et al., 2020; Chung, Chan, Lanier, \& Wong, 2020; Spinelli, Lionetti, Pastore, \& Fasolo, 2020). Na základe syntézy výsledkov viacerých zahraničných štúdií zaradili Nobles, Martin, Dawson, Moran, \& Savovic (2020) rodičov a deti medzi skupiny rizikové na negatívne psychologické dopady pandémie. $\mathrm{V}$ dôsledku krízového stavu prechádzali rodiny významnými zmenami a boli vystavené vyššej miere stresu a úzkosti (Dalton, Rapa, \& Stein, 2020).

Pre väčšinu l’udí pandémia koronavírusu znamenala tiež významný zásah do pracovného režimu, či už v zmysle straty zamestnania, zmeny formy vykonávania práce alebo pretrvávajúceho dochádzania do práce $\mathrm{v}$ podmienkach krízového stavu. $\mathrm{Z}$ výsledkov anglickej štúdie Co-SPACE vyplýva, že práca bola najčastejším zdrojom stresu pre rodičov v čase pandémie koronavírusu (Waite, Patalay, Moltrecht, McElroy, \& Creswell, 2020). Zamestnanie je pritom jedným $z$ významných prediktorov duševného zdravia jednotlivcov, ktorý zároveň ovplyvňuje chod celej rodiny (Duffy, Blustein, Diemer, \& Autin, 2016). Podla štúdie CBRE (2020) mala pandémia koronavírusu nezanedbatel'ný dopad na situáciu na pracovnom trhu. $Z$ dát tohto prieskumu v 27 členských štátoch Európskej únie vyplýva, že 5 \% respondentov stratilo svoju prácu natrvalo a 23 \% respondentov dočasne z dôvodu opatrení proti šíreniu Covid-19. Na Slovensku počet nezamestnaných mierne vzrástol v marci, kedy sa obmedzil najmä nábor nových zamestnancov, ale aprílový nárast nezamestnanosti z 6,2 \% na 7,4 \% bol historicky najvyšším medzimesačným nárastom nezamestnanosti, ktorý prekonal aj krízu v roku 2009 (Národná Banka Slovenska, 2020). Kvôli pandémii koronavírusu a s tým súvisiacim uzavretím podnikov či prevádzok sa taktiež zvýšil počet l'udí obávajúcich sa prepustenia (Karpman, Zuckerman, \& Peterson, 2020; Zhou, Hertog, Kolpashnikova, \& Kan, 2020), čo podla Blusteina (2019) spôsobuje chronický stres, negatívne vplýva na duševné i fyzické zdravie a zvyšuje tiež riziko problémov v partnerskej oblasti.

Okrem zamestnania stáli pred rodičmi počas opatrení v súvislosti s pandémiou d’alšie úlohy v podobe starostlivosti o deti, ich vzdelávania a tiež bežnej údržby domácnosti, ktoré najmä vzhl'adom na uzatvorenie škôl a školských zariadení, predstavovali pre rodičov významne väčšiu časovú zátaž. Podla analýzy skúmajúcej život anglických rodín počas pandemických opatrení venovali rodičia starostlivosti o deti 9 hodín denne, pričom v porovnatel'nom prieskume $z$ rokov 2014-2015 to bolo 5 a pol hodiny denne. Rodičia pritom často vykonávali viac ako dve aktivity naraz (Andrew et al., 2020). Zabezpečenie rovnováhy medzi pracovným a osobným životom bolo v tomto období pre rodičov 
tažkou úlohou. Podl’a výsledkov prieskumu Eurofound (2020) v krajinách Európskej únie sa tento problém týkal najmä rodičov detí s menšími det’mi. Rodičia detí vo veku do 12 rokov častejšie ( $22 \%$ ) uvádzali tažkosti so sústredením sa na prácu a s rozdelením času medzi prácu a rodinu v porovnaní s rodičmi starších detí vo veku od 12 do 17 rokov (7 \%) a dospelými bez detí (5\%). Rovnováha medzi prácou a ostatnými aspektmi osobného života má pritom významný vplyv na preživanie rodiča a rodinnú pohodu. Podla výskumu zo Singapuru, tí rodičia, ktorí uvádzali vyššiu mieru rovnováhy medzi pracovným a osobným životom a tiež vyššiu mieru podpory od partnera a zamestnávatel’a počas karanténnych opatrení, zažívali menej rodičovského stresu a menej partnerských konfliktov (Chung et al., 2020).

Pandémia koronavírusu mala za následok tiež prehlbovanie rozdielov medzi mužmi a ženami a to hned' vo viacerých oblastiach života, vrátane zamestnanosti, miezd, domácich prác a starostlivosti o deti (Devine \& Foley, 2020). U žien, najmä matiek, bol zaznamenaný výraznejší pokles duševného zdravia a blahobytu počas korona krízy (Zhou et al., 2020). Okrem horšieho postavenia matiek na trhu práce, to spôsobilo najmä navýšenie povinností a to, že $\mathrm{v}$ porovnaní s otcami dávali pred prácou prednost' starostlivosti o deti a o domácnost'. Pracujúce matky počas pandémie častejšie prerušovali čas venovaný práci d’alšími aktivitami, vo väčšine prípadov starostlivostou o deti, a celkovo venovali práci menej času ako muži (Andrew et al., 2020). Podla prieskumu rodičov z Anglicka, USA a Talianska (Biroli et al., 2020) bola počas pandemických opatrení v mnohých rodinách starostlivost’ o deti a o domácnost’ nad’alej výlučne v kompetencii žien, no celkovo narástol podiel rodín zdiel'ajúcich starostlivost’ o deti a domáce práce. $Z$ dát tiež vyplynulo, že s del'bou povinností súvisí vnímaná úroveň domáceho napätia a tiež hádky medzi partnermi, konkrétne v domácnostiach, kde sa zmenilo prerozdelenie povinností, sa partneri hádali viac, ako $v$ tých domácnostiach, kde del'ba práce ostala rovnaká ako pred pandémiou koronavírusu. $\mathrm{V}$ domácnostiach, kde si partneri delia domáce povinnosti a starostlivost' o deti, bola zaznamenaná najnižšia miera domáceho napätia (Biroli et al., 2020). Zvýšený stres a napätie v rodinách, neistota a t’ažkosti v zamestnaní, prerušenie kontaktov a sociálna izolácia môžu viest’ k zvýšeniu miery už existujúceho domáceho násilia v rodinách a k vzniku nových prípadov, a ako sa ukázalo, ide o celosvetový dramatický nárast tohto problému, ktorý si vyžaduje hlbšie skúmanie a najmä prevenciu a riešenie, ak by došlo k d’alším opatreniam v súvislosti s pandémiou (Beland, Brodeur, Haddad, \& Mikola, 2020).

Medzi obzvlášt pandémiou ohrozené skupiny patria jednorodičovské rodiny, pričom podl’a štatistík (Prognostický ústav Slovenskej akadémie vied; INFOSTAT - Výskumné demografické centrum; Katedra humánnej geografie a demografie Prírodovedeckej fakulty Univerzity Komenského, 2014) je vo väčšine prípadov na čele týchto rodín žena - matka. Británia počas obdobia pandémie koronavírusu zaznamenala 7\%-ný nárast nepracujúcich single rodičov (jeden rodič v domácnosti). Samotný výkon práce single rodičov bol st’ažený tým, že v dôsledku dodržiavania sociálnej vzdialenosti boli podporné siete zabezpečujúce a pomáhajúce so starostlivostou o diet’a, napr. starí rodičia, obmedzené. Nakolko britské single matky častejšie pracujú v zamestnaniach, ktoré neumožňujú prácu $\mathrm{z}$ domu a častejšie sa musia spoliehat’ na verejnú dopravu, ked’že mnohé nevlastnia auto, sú tiež 
považované za ohrozenejšie čo sa týka vystavenia nákaze koronavírusom. Single rodičia mali tiež vyššie riziko depresie (Zhou et al., 2020).

Zvýšenú náročnost' mohlo toto obdobie priniest' aj pre rodiny s deṫmi so špeciálnymi potrebami, ktoré mali kvôli pandemickým opatreniam stažený prístup k odbornej pomoci. V Británii až $85,5 \%$ rodín s deṫmi so špeciálnymi potrebami nedostávalo podporu a služby, ktoré mali k dispozícii pred pandémiou koronavírusu (Waite et al., 2020). Táto skutočnosṫ spolu s domácim vzdelávaním, pracovnými povinnostami, starostlivostou o domácnost', nehovoriac o sociálne-ekonomickom znevýhodnení a tiež ekonomických dopadoch pandémie, mohli znásobit fyzické a duševné problémy rodiča, ale aj samotného dietata (Holmes et al., 2020). V prieskume Co-SPACE (Waite et al., 2020) v Anglicku bola $u$ rodičov s detmi so špeciálnymi výchovno-vzdelávacími potrebami a zdravotným postihnutím zaznamenaná zvýšená úroveň stresu počas pandémie, pričom jeho zdrojmi boli najmä obavy o blaho dietata, strata sociálneho kontaktu a podpory, vzdelávanie a správanie diet’ata, či zabezpečenie stravy.

Je teda zrejmé, že pandémia koronovírusu priniesla nové výzvy rodinám s detmi po celom svete, pričom jej dopady zahŕňali aspekt ekonomický, sociálny aj psychologický. Nakolko COVID-19 a opatrenia prijaté proti jeho šíreniu zasiahli do životov slovenských rodín bolo zistované $\mathrm{v}$ predmetnom výskume.

\section{Výskumný ciel'}

Ciel'om predkladanej štúdie bolo zistit', nakolkko bol nástup pandémie koronavírusu stresujúci pre rodiny s detmi na Slovensku a ako rodičia vnímali dopady pandémie na svoj život a život rodiny. Výskumom bolo tiež zistované, ktoré z rodín boli nástupom pandémie koronavírusu najviac zasiahnuté, preto sme sa zamerali na exploráciu súvislostí medzi mierou prežívania rodinnej krízy a d’alšími premennými (konkrétne: osobná skúsenost' s koronavírusom, kraj, aktuálna forma vykonávania práce, typ rodinnej domácnosti, počet detí a špeciálne výchovno-vzdelávacie potreby u detí).

\section{Metódy}

Dáta boli získavané formou online dotazníka pozostávajúceho z niekolkých častí. Po udelení informovaného súhlasu s účastou vo výskume nasledovala sekcia zistujúca základné sociodemografické údaje, ako sú vek, pohlavie, vzdelanie, kraj, velkost̉ sídla, aktuálna forma vykonávania práce, či typ rodinnej domácnosti (jeden rodič v domácnosti/dvaja rodičia $v$ domácnosti/viacgeneračná domácnost'). $V$ tejto časti sa tiež nachádzali otázky venované počtu a veku detí respondenta, či prítomnosti špeciálnych výchovno-vzdelávacích potrieb u detí. Jedna $\mathrm{z}$ otázok zistovala tiež osobnú skúsenost́ respondentov s ochorením Covid-19, prípadne výskyt ochorenia u blízkych alebo známych osôb. Pre účely tohto výskumu analyzujeme výsledky Krátkej škály rodinného distresu (angl. Brief Family Distress Scale; Weiss \& Lunsky, 2012). Tento nástroj zistuje mieru prežívania krízy v rodine (Weiss $\&$ Lunsky, 2011). Tvorí ho jedna položka pozostávajúca $\mathrm{z}$ desiatich 
výrokov, ktoré predstavujú 10-bodovú škálu. V našom výskume bolo znenie položky doplnené tak, aby sa respondenti vyjadrovali o aktuálnej situácii v rodine v kontexte koronavírusovej krízy. Výroky škály pôvodne vznikli na základe rozhovorov s rodičmi osôb s vývinovými poruchami alebo duševnými ochoreniami a opisujú rodinnú situáciu na škále od neprítomnosti stresu až po úplnú krízu (Weiss \& Lunsky, 2011). Úlohou respondenta je vybrat' jeden $\mathrm{z}$ desiatich výrokov, ktorý najlepšie vystihuje aktuálnu situáciu rodiny. V príspevku tiež analyzujeme odpovede respondentov na otvorenú otázku „Ako vnimate dopad mimoriadnej situácie na Váš osobný život?“. Vzhl’adom na celkové zameranie dotazníka na prežívanie pandémie koronavírusu boli respondenti inštruovaní vyjadrovat' sa k mimoriadnej pandemickej situácii.

Ďalšie sekcie dotazníka, ktoré však nie sú predmetom tejto štúdie, boli venované aktuálnemu preživaniu respondentov, sledovaniu mediálnych správ o pandémií, vnímaniu súvisiacich opatrení a poslednú čast’ tvorili položky týkajúce sa dištančného vzdelávania, jeho priebehu v domácom prostredí a s tým súvisiacimi obavami, či vnímanými nedostatkami. V závere dotazníka boli okrem pod’akovania uvedené telefonické a mailové kontakty, na ktorých bola respondentom v prípade potreby poskytnutá odborná psychologická podpora.

\section{Priebeh výskumu}

Zber dát prostredníctvom online dotazníka prebiehal v období od 14.4. do 19.5. 2020, kedy na území Slovenska platili opatrenia podporujúce spoločenský odstup, vrátane uzatvorenia škôl a školských zariadení. Starostlivost’ o deti, vrátane ich vzdelávania, bola preto $\mathrm{v}$ tomto období primárne zodpovednostou rodičov. Dotazník bol šírený v online priestore prostredníctvom webových, facebookových stránok a newslettera Výskumného ústavu detskej psychológie a patopsychológie, bol zverejnený vo facebookových skupinách združujúcich rodičov, ktorí sa zaujímajú o problematiku školstva a domáceho vzdelávania a tiež bol zaslaný e-mailom združeniam rodičov detí s rôznymi špeciálnymi potrebami. Dotazník bol pre respondentov $\mathrm{k}$ dispozícii v slovenskej aj mad’arskej jazykovej verzii. Mad’arská verzia dotazníka bola preložená zo slovenčiny metódou spätného prekladu.

\section{Výskumný súbor}

Výskumný súbor tvorilo 458 respondentov, s vel'kou prevahou žien $(\mathrm{n}=424)$. Vek respondentov sa pohyboval od 25 do 62 rokov, pričom priemerný vek bol 40,7 rokov ( $S D=5,94 ; 21$ respondentov neuviedlo svoj vek). Vo výskumnom súbore boli zastúpení respondenti zo všetkých krajov Slovenska, no najviac, až 20,3 \% respondentov žije v Bratislavskom kraji (15,9 \% Trnavský, 12,2 \% Trenčiansky, 12 \% Nitriansky, 11,6 \% Žilinský, 10,3 \% Banskobystrický, 8,5 \% Prešovský, 8,3 \% Košický kraj, 0,9 \% neuvedený). Väčšina respondentov, až 68,1 \%, má ukončené vysokoškolské vzdelanie (1., 2. alebo 3. stupňa), 30,3 \% stredoškolské vzdelanie, necelé $1 \%$ základoškolské. Respondenti sú rodičmi jedného až siedmich detí vo veku od niekolkých mesiacov až po 35 rokov (M=11,23; SD=6,06; Q1=7; Q3=15). Rodičia, 
ktorých prvé dieta bolo staršie ako 24 rokov, mali zároveň druhé dieta alebo viac detí nižšieho veku. $Z$ výskumného súboru 20,7 \% všetkých rodičov má aspoň jedno dieta s identifikovanými špeciálnymi výchovno-vzdelávacími potrebami.

\section{Spracovanie výskumných dát}

Dáta boli spracované pomocou programu SPSS verzia 22 pre Windows a STATA verzia 13. Boli použité metódy deskriptívnej štatistiky (počet, aritmetický priemer, štandardná odchýlka, štandardná chyba priemeru, šikmost', špicatost', minimum, maximum a percentá) a metódy inferenčnej štatistiky: testy normality distribúcie dát (konkrétne Shapiro-Wilk test pre analýzu normality dát podsúborov s vel'kostou $\mathrm{n} \leq 50$, a Kolmogorov-Smirnov test pre analýzu normality dát podsúborov s velkost’ou n>50; Elliott \& Woodward, 2007), kde v prípade nesplnenia kritérií normality distribúcie dát a nerovnomernosti velkosti porovnávaných skupín boli volené neparametrické testy; a komparačné testy (ANOVA, Mann-Whitney U test). Odpovede respondentov na otvorenú otázku („Ako vnímate dopad mimoriadnej situácie na Váš osobný život?“) boli podrobené konceptualizácií a následnej kategorizácií. Na analýze otvorenej otázky sa podielali dvaja výskumníci. Za účelom zvýšenia reliability boli jednotlivé kategórie následne podrobené komparácií.

\section{Výsledky}

V tabul'ke 1 sú uvedené výsledky deskriptívnej štatistiky odpovedí na Krátku škálu rodinného distresu. $Z$ celkového počtu respondentov $(N=458)$ až 32,10 \% volilo odpoved' 3 „Niekedy sme v strese, ale dokážeme sa vysporiadat’ s problémami, ktoré sa objavia“ a až 30,35\% respondentov volilo odpoved' 2 „Všetko je v poriadku, ale občas máme nejaké problémy“. Tieto dve odpovede boli najfrekventovanejšie a za nimi nasledovali odpovede 1 a 4 („1. Všetko je v poriadku, ja a moja rodina nepocitujeme krízu vôbec“ - 16,59 \%; „4. Často sme v strese, ale darí sa nám vysporiadat’ s problémami, ked’ sa objavia“ - 13,54 \%), ktoré mali približne o polovicu menšie zastúpenie v porovnaní s odpoved’ami 2 a 3. Podiel respondentov, ktorí zvolili odpovede 5 a vyššie, bol výrazne nižší, menej ako 5 \%. Posledná odpoved', ktorá opisovala najzávažnejšiu situáciu krízy v rodine v našej výskumnej skupine nebola zvolená ani jedným respondentom. Odpovede 1 až 5, ktoré opisovali žiadnu, alebo mierne závažnú krízu v rodine, volilo spolu 97,16 \% respondentov, kým zvyšných pät, ktoré opisovali závažnejšie krízové situácie v rodine, volilo spolu 2,84 \%. Aritmetický priemer odpovedí bol $M=2,71$ so štandardnou odchýlkou $S D=1,320$. Distribúcia odpovedí je znázornená pomocou grafu 1 . 
Tabul'ka 1

Počty a percentuálne zastúpenie odpovedí v dotazníku Krátka škála rodinného distresu

\begin{tabular}{|c|c|c|c|}
\hline $\begin{array}{l}\text { Na stupnici od } 1 \text { do } 10 \text { prosím ohodnot'te, kde sa momentálne } \\
\text { Vy a Vaša rodina nachádzate, v kontexte koronavírusovej krízy }\end{array}$ & $\mathrm{n}$ & Percentá & $\begin{array}{l}\text { Kumulatívne } \\
\text { percentá }\end{array}$ \\
\hline $\begin{array}{l}\text { 1. Všetko je v poriadku, ja a moja rodina nepocitujeme krízu } \\
\text { vôbec. }\end{array}$ & 76 & 16,5 & 16,5 \\
\hline 2. Všetko je v poriadku, ale občas máme nejaké problémy. & 139 & 30,3 & 46,9 \\
\hline $\begin{array}{l}\text { 3. Niekedy sme v strese, ale dokážeme sa vysporiadat' s problé- } \\
\text { mami, ktoré sa objavia. }\end{array}$ & 147 & 32,1 & 79,0 \\
\hline $\begin{array}{l}\text { 4. Často sme v strese, ale darí sa nám vysporiadat's problémami, } \\
\text { ked' sa objavia. }\end{array}$ & 62 & 13,5 & 92,5 \\
\hline 5. Často sme vo vel'kom strese, ale s velkým úsilím ho zvládame. & 21 & 4,5 & 97,1 \\
\hline $\begin{array}{l}\text { 6. Musíme vel'mi t’ažko pracovat' každú minútu každého dňa, } \\
\text { aby sme sa vyhli kríze. }\end{array}$ & 4 & 0,8 & 98,0 \\
\hline $\begin{array}{l}\text { 7. Čoskoro nebudeme schopní zvládat’ problémy. Ak sa pokazí } \\
\text { ešte jedna vec, budeme mat’ krízu. }\end{array}$ & 3 & 0,6 & 98,6 \\
\hline 8. Momentálne sme v kríze, ale sami sa s tým vysporiadame. & 5 & 1,0 & 99,7 \\
\hline $\begin{array}{l}\text { 9. Momentálne sme v kríze a požiadali sme o pomoc krízové } \\
\text { centrá/odborníkov. }\end{array}$ & 1 & 0,2 & 100,0 \\
\hline 10. Momentálne sme v kríze a už to nemôže byt' horšie. & 0 & 0,0 & 100,0 \\
\hline
\end{tabular}

Tabul'ka 2

Opisná štatistika odpovedí v dotazníku Krátka škála rodinného distresu

$\begin{array}{llllllll}\text { N } & \text { MIN } & \text { MAX } & \text { M } & \text { SEM } & \text { SD } & \gamma 1 & \gamma 2 \\ 458 & 1 & 9 & 2,71 & 0,062 & 1,320 & 1,265 & 3,113\end{array}$

Pozn.: N - počet respondentov; MIN - minimum; MAX - maximum; M - priemer; SEM - štandardná chyba priemeru; SD - štandardná odchýlka; $\gamma^{1}$ - šikmost'; $\gamma^{2}$ - špicatost'.

\section{Graf 1}

Distribúcia odpovedí preživania krízy v rodine počas Covid-19 pandémie

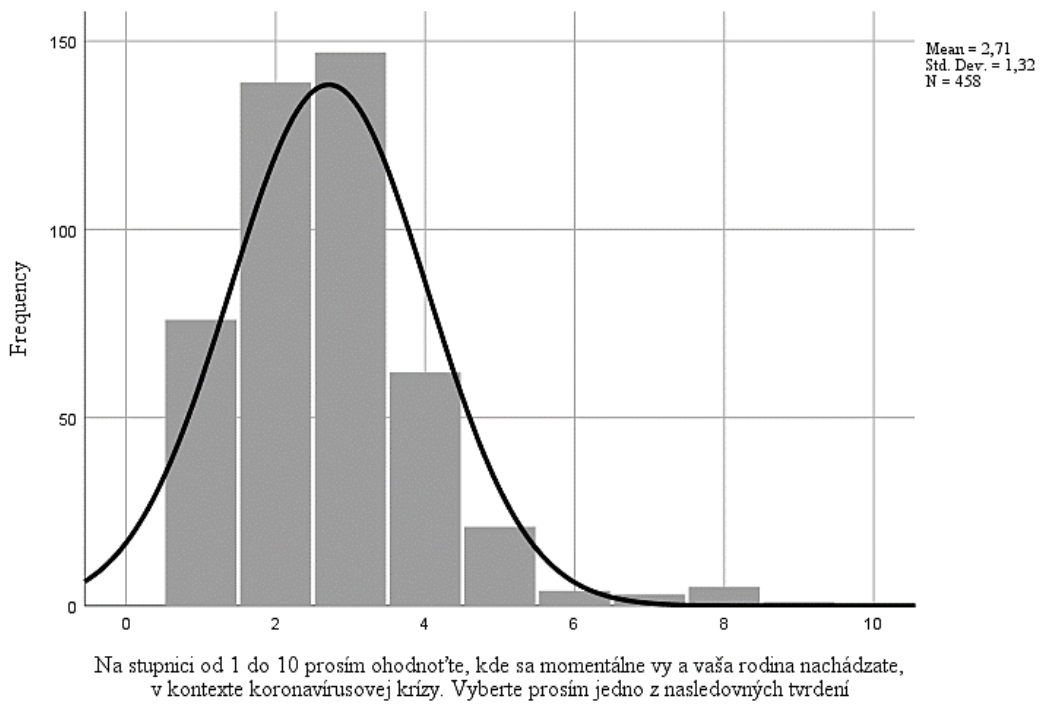


Z celej výskumnej vzorky 14 respondentov (Bratislavský kraj $n=7$ ) uviedlo, že niekto $z$ ich blízkych/známych bol nakazený koronavírusom, kým záporne na túto otázku odpovedalo $\mathrm{n}=441$ respondentov. Respondenti, ktorí uviedli, že niekto $\mathrm{z}$ ich blízkych/známych bol nakazený koronavírusom získali o približne 0,7 bodu vyššie priemerné skóre, v porovnaní so skupinou respondentov, ktorí na túto otázku odpovedali záporne. Vzhl’adom na rozdiely vo vel'kosti výskumných skupín a výsledkov normality distribúcie dát bol zvolený neparametrický test pre testovanie hypotézy (Mann-Whitney U test). Rozdiel priemerov nebol štatisticky významný (U=15,315; p=0,053; Tab. 3).

\section{Tabul'ka 3}

Rozdiely v prežívani krizy v rodine počas Covid-19 pandémie vzhl'adom na pritomnost' alebo neprítomnost' nakazenia blizkeho/rodinného príslušníka zistované pomocou Mann-Whitney U testu

\begin{tabular}{lllllllll}
$\begin{array}{l}\text { Niekto z mojich blízkych/známych } \\
\text { bol/a nakazený/á koronavírusom }\end{array}$ & $\mathrm{n}$ & $\mathrm{M}$ & $\mathrm{SD}$ & $\mathrm{SEM}$ & $\gamma 1$ & $\gamma 2$ & $\mathrm{U}$ & $\mathrm{p}$ \\
\hline Nie & 441 & 2,69 & 1,292 & 0,062 & 1,238 & 3,193 & & \\
Áno & 14 & 3,36 & 2,023 & 0,541 & 0,990 & 0,560 & 15,315 & 0,053 \\
Spolu & 455 & 2,71 & 1,322 & 0,062 & 1,265 & 3,111 & &
\end{tabular}

Pozn. n- počet respondentov; M- priemer; SD- štandardná odchýlka; SEM- štandardná chyba priemeru; $\gamma^{1}$ - šikmost'; $\gamma^{2}$ - špicatost'; U- Mannov-Whitneyov U test; p- hladina významnosti.

V Tabulke 4 uvádzame výsledky opisnej štatistiky (počet respondentov, priemer, štandardnú odchýlku, štandardnú chybu priemeru, šikmost’ a špicatost’ dát) a výsledky analýzy rozptylu (ANOVA) v miere prežívania krízy v rodine vzhladom na kraje Slovenskej republiky. Vo všetkých krajoch bolo u respondentov namerané porovnatel’né priemerné skóre, vzhl’adom na možné maximálne a minimálne dosiahnutel’né skóre. Najnižšie priemerné skóre bolo namerané v Trenčianskom $(M=2,41)$, Prešovskom $(M=2,51)$ a Trnavskom kraji $(\mathrm{M}=2,53)$, kým najvyššie priemerné skóre bolo namerané $\mathrm{v}$ Banskobystrickom $(\mathrm{M}=3,04)$ a Bratislavskom kraji $(M=2,95)$. Rozdiel medzi priemernými skóre sú napriek tomu malé, rozdiel medzi najvyšším a najnižším nameraným priemerným skóre je približne 0,6 bodu. Pri d’alších inferenčných analýzach nebol zistený rozdiel rozptylov medzi respondentmi $\mathrm{z}$ rôznych krajov $(\mathrm{F}=19,905 ; \mathrm{p}=0,120)$. Napriek tomu, rozdiel priemerov medzi Banskobystrickým krajom a Trnavským ( $p=0,039)$ a Trenčianskym krajom $(p=0,015)$ je štatisticky významný, a taktiež je štatisticky významný aj rozdiel priemerov medzi Bratislavským a Trnavským ( $\mathrm{p}=0,046)$ a Trenčianskym krajom $(\mathrm{p}=0,016)$ v miere prežívania krízy v rodine (na základe Bonferroni analýzy komparácie priemerov).

Tabul'ka 4

Rozdiely v preživaní krízy v rodine počas Covid-19 pandémie vzhl'adom na kraj zistované pomocou analýzy rozptylu ANOVA

\begin{tabular}{lllllllll} 
Kraj & $\mathrm{n}$ & $\mathrm{M}$ & $\mathrm{SD}$ & $\mathrm{SEM}$ & $\gamma^{1}$ & $\gamma^{2}$ & $\mathrm{~F}$ & $\mathrm{p}$ \\
\hline Bratislavský & 93 & 2,95 & 1,499 & 0,155 & 1,696 & 4,377 & 19,905 & 0,120 \\
Trnavský & 73 & 2,53 & 1,168 & 0,137 & 0,561 & $-0,374$ & & \\
Trenčiansky & 56 & 2,41 & 1,156 & 0,155 & 0,664 & $-0,161$ & &
\end{tabular}




\begin{tabular}{lllllll} 
Nitriansky & 55 & 2,64 & 1,310 & 0,177 & 1,331 & 3,817 \\
\hline Žilinský & 53 & 2,70 & 1,186 & 0,163 & 0,835 & 2,201 \\
\hline Banskobystrický & 47 & 3,04 & 1,429 & 0,208 & 1,463 & 3,075 \\
\hline Prešovský & 39 & 2,51 & 1,048 & 0,168 & $-0,036$ & $-1,146$ \\
Košický & 38 & 2,82 & 1,557 & 0,253 & 1,366 & 2,331 \\
\hline Spolu & 454 & 2,71 & 1,320 & 0,062 & 1,281 & 3,158
\end{tabular}

Pozn. $\mathrm{n}$ - počet respondentov; M - priemer; SD - štandardná odchýlka; SEM - štandardná chyba priemeru; $\gamma^{1}$ - šikmost'; $\gamma^{2}$ - špicatost'; F - ANOVA; p - hladina významnosti.

V Tabul'ke 5 sú uvedené výsledky opisnej a inferenčnej štatistiky miery prežívania krízy v rodine vzhl'adom na formu vykonávania práce počas koronavírus pandémie. U všetkých podskupín bolo namerané porovnatel’né priemerné skóre, vzhl’adom na možné maximálne a minimálne dosiahnutel'né skóre. Rovnaké priemerné skóre bolo namerané u respondentov, ktorí počas pandémie boli nezamestnaní v dôsledku Covid-19 a u respondentov, ktorí počas pandémie dochádzali do práce $(\mathrm{M}=2,91)$. O niečo nižšie priemerné skóre bolo namerané aj u respondentov, ktorí boli nezamestnaní, avšak nie v dôsledku pandémie Covid-19. Najnižšie skóre bolo namerané u respondentov, ktorí pracovali z domu alebo boli na rodičovskej dovolenke. Medzi skupinami nebol zistený rozdiel rozptylov $(F=40,351 ; p=0,455)$ na základe analýzy rozptylu ANOVA. Štatisticky významný rozdiel priemerov bol zistený iba medzi respondentmi, ktorí sú na rodičovskej dovolenke $(\mathrm{p}=0,045)$ a respondentmi, ktorí dochádzali do práce alebo zostali nezamestnaní v dôsledku Covid-19 na základe Bonferroni analýzy komparácie priemerov.

\section{Tabul'ka 5}

Rozdiely v preživani krízy v rodine vzhl’adom na formu vykonávania práce počas Covid-19 pandémie zistované pomocou analýzy rozptylu ANOVA

$\begin{array}{lllllllll}\text { Forma vykonávania práce počas } & \mathrm{n} & \mathrm{M} & \mathrm{SD} & \mathrm{SEM} & \gamma^{1} & \gamma^{2} & \mathrm{~F} & \mathrm{p} \\ \text { koronavírus pandémie } & 96 & 2,91 & 1,362 & 0,139 & 1,041 & 1,897 & & \\ \text { Dochádzam do práce } & 22 & 2,86 & 1,885 & 0,402 & 1,389 & 1,984 & & \\ \text { Nezamestnaný/á } & 23 & 2,91 & 1,041 & 0,217 & 0,187 & 0,230 & & \\ \text { Nezamestnaný/á v dôsledku Covid } & 243 & 2,63 & 1,264 & 0,081 & 1,341 & 3,957 & 40,351 & 0,455 \\ \text { Home Office } & 22 & 2,77 & 1,193 & 0,254 & 0,112 & -0,441 & & \\ \text { OČR } & 36 & 2,39 & 1,358 & 0,226 & 2,060 & 7,226 & & \\ \text { Rodičovská dovolenka } & 445 & 2,70 & 1,316 & 0,062 & 1,257 & 3,132 & & \end{array}$

Pozn. n - počet respondentov; M - priemer; SD - štandardná odchýlka; SEM - štandardná chyba priemeru; $\gamma^{1}$ - šikmost; $\gamma^{2}$ - špicatost; F - ANOVA; OČR - ošetrovanie člena rodiny; $\mathrm{p}$ - hladina významnosti.

V nasledovnej časti sme sa zamerali na analýzu premenných týkajúcich sa vybraných charakteristík rodinného prostredia: typ rodiny, počet detí a ich špeciálne potreby. V Tabul'ke 6 sú uvedené výsledky analýz zistujúcich mieru prežívania krízy vzhl’adom na typ rodiny. Najzastúpenejšou skupinou boli rodiny s dvoma rodičmi v domácnosti 
( $n=336)$. V dvojrodičovských rodinách a viacgeneračných rodinách bolo namerané nižšie priemerné skóre ako u rodín s jedným rodičom (o približne 0,4 bodu). Pri inferenčných analýzach nebol zistený rozdiel rozptylov medzi uvedenými skupinami respondentov ( $F=9,061 ; p=0,075)$ na základe analýz rozptylu ANOVA, avšak existuje štatisticky významný rozdiel priemerov $(\mathrm{p}=0,026) \mathrm{v}$ miere prežívania krízy medzi rodinami s dvoma rodičmi a rodinami s jedným rodičom počas pandémie koronavírusu na základe Bonferroni analýzy komparácie priemerov.

Tabul'ka 6

Rozdiely $v$ preživani krízy v rodine počas Covid-19 pandémie vzhladom na typ rodiny zistované pomocou analýzy rozptylu ANOVA

$\begin{array}{llllllllll}\text { Typ rodiny } & \mathrm{n} & \mathrm{M} & \mathrm{SD} & \mathrm{SEM} & \gamma^{1} & \gamma^{2} & \mathrm{~F} & \mathrm{p} & \\ \text { Dvaja rodičia v domácnosti } & 336 & 2,66 & 1,202 & 0,066 & 0,933 & 2,159 & & & \\ \text { Jeden rodič v domácnosti } & 62 & 3,06 & 1,854 & 0,235 & 1,497 & 2,262 & & \\ \text { Viacgeneračná rodina } & 57 & 2,63 & 1,277 & 0,169 & 0,843 & 0,389 & & 0,075 \\ \text { Spolu } & 455 & 2,71 & 1,322 & 0,062 & 1,269 & 3,113 & & \end{array}$

Pozn. n - počet respondentov; M - priemer; SD - štandardná odchýlka; SEM - štandardná chyba priemeru; $\gamma^{1}$ - šikmost; $\gamma^{2}$ - špicatost'; F - ANOVA; p - hladina významnosti.

V Tabul'ke7 sú uvedené výsledky zistujúce súvis medzi prežívaním krízy v rodine a počtom detí v rodine. Vo všetkých výskumných skupinách bola zistená porovnatel’ná miera prežívania krízy v rodine, ale najvyššie priemerné skóre bolo namerané u rodín, ktoré majú 4 a viac detí $(M=2,87)$. Avšak, nebol zistený štatisticky významný rozdiel rozptylov v miere prežívania krízy vzhl'adom na počet detí v rodine $(\mathrm{F}=1,421 ; \mathrm{p}=0,846)$ na základe analýzy rozptylu ANOVA.

\section{Tabul'ka 7}

Rozdiely v prežívaní krízy v rodine počas Covid-19 pandémie vzhladom na počet detí v rodine zistované pomocou analýzy rozptylu ANOVA

$\begin{array}{lllllllll}\text { Počet detí } & \mathrm{n} & \mathrm{M} & \mathrm{SD} & \mathrm{SEM} & \gamma^{1} & \gamma^{2} & \mathrm{~F} & \mathrm{p} \\ 1 & 95 & 2,64 & 1,383 & 0,142 & 1,657 & 5,471 & & \\ 2 & 258 & 2,73 & 1,295 & 0,081 & 1,091 & 2,184 & & \\ 3 & 79 & 2,65 & 1,241 & 0,140 & 1,165 & 3,203 & 1,421 & 0,846 \\ 4 \text { a viac } & 23 & 2,87 & 1,604 & 0,334 & 1,751 & 4,077 & & \\ \text { Spolu } & 455 & 2,70 & 1,318 & 0,062 & 1,284 & 3,193 & & \end{array}$

Pozn. $\mathrm{n}$ - počet respondentov; $\mathrm{M}$ - priemer; SD - štandardná odchýlka; SEM - štandardná chyba priemeru; $\gamma^{1}$ - šikmost; $\gamma^{2}$ - špicatost; $\mathrm{F}$ - ANOVA; $\mathrm{p}$ - hladina významnosti.

V nasledovnej časti sme sa zamerali aj na analýzu súvislosti medzi prežívaním krízy $\mathrm{v}$ rodinách a prítomnostou špeciálnych výchovno-vzdelávacích potrieb $\mathrm{u}$ detí $\mathrm{v}$ týchto rodinách. $\mathrm{V}$ rodinách $\mathrm{s}$ det’mi so špeciálnymi výchovno-vzdelávacími potrebami bola zistená štatisticky významne vyššia $(t=3,208 ; p=0,001)$ miera pocitovania krízy $(M=3,09)$, $\mathrm{v}$ porovnaní s rodinami bez detí so špeciálnymi výchovno-vzdelávacími potrebami $(\mathrm{M}=2,61)$ na základe Studentovho t-testu. 


\section{Tabul'ka 8}

Rozdiely v preživani krizy v rodine počas Covid-19 pandémie vzhladom na ne/pritomnost'špeciálnych výchovno-vzdelávacích potrieb detí zistované pomocou Studentovho t-testu

\begin{tabular}{llllllllll}
$\begin{array}{l}\text { Má niektoré z Vašich detí špeciálne } \\
\text { výchovno-vzdelávacie potreby? }\end{array}$ & $\mathrm{N}$ & $\mathrm{M}$ & $\mathrm{SD}$ & $\mathrm{SEM}$ & $\gamma^{1}$ & $\gamma^{2}$ & $\mathrm{t}$ & $\mathrm{p}$ & \\
\hline Nie & 363 & 2,61 & 1,259 & 0,066 & 1,156 & 2,963 & & \\
Áno & 95 & 3,09 & 1,474 & 0,151 & 1,443 & 2,895 & 3,208 & 0,001 \\
Spolu & 458 & 2,71 & 1,320 & 0,062 & 1,265 & 3,113 & &
\end{tabular}

Pozn. n - počet respondentov; M - priemer; SD - štandardná odchýlka; SEM - štandardná chyba priemeru; $\gamma^{1}$ - šikmost'; $\gamma^{2}$ - špicatost; Studentov t-test; $p$ - hladina významnosti.

V poslednej časti interpretujeme sumarizáciu výsledkov otvorenej otázky „Ako vnímate dopad mimoriadnej situácie na Váš osobný život?“. Na uvedenú otázku sme spolu zaznamenali 491 odpovedí, ktoré boli následne kategorizované do nižšie uvedených kategórií (Tab. 9). Na otázku neodpovedalo 34 respondentov. Približne 12,8 \% odpovedí opisovalo, že mimoriadna situácia spojená s pandémiou Covid-19 nemala žiaden dopad na osobný život respondentov, kým v 10,4 \% odpovedí bolo vyjadrené, že vzniknutá situácia pozitívne ovplyvnila život respondentov (pokojnejší život, spomalenie životného tempa, využitie času pre domáce práce, čas na sebarozvoj, atd’.). Ďalšie frekventované odpovede, ktoré mali negatívny charakter, boli: spojené s dopadom na psychické zdravie (stres, strach, obavy; 9,4\%); strata sociálnych kontaktov (9,4\%); obavy o deti (starosti spojené so školou a výchovou, trávením vol'ného času, zdravím, atd’, 8,4 \%); zamestnanie a príjem (8,1 \%); všeobecne negatívny dopad (negatívne skúsenosti, staženie života a žitia, chodu domácnosti a povinností; 8,1 \%). Ostatné, menej frekventované odpovede sa týkali vol’ného času, času a priestoru pre seba, neakceptácie nariadení a príkazov štátu, atd. V odpovediach sa v menšej miere vyskytovali aj d’alšie odpovede, ktoré mali pozitívny charakter, ako napríklad vnímanie vzniknutej situácie ako novej životnej výzvy (5,9 \%), viac času pre seba (3,5\%), viac času pre partnera/ku alebo iných rodinných príslušníkov (5,5\%), atd’.

Tabul'ka 9

Vnímanie dopadu pandémie Covid-19 na osobný život

\begin{tabular}{|llll}
\hline Ako vnímate dopad mimoriadnej situácie na Váš osobný život? & $\mathrm{n}$ & Percentá & $\begin{array}{l}\text { Kumulatívne } \\
\text { percentá }\end{array}$ \\
\hline Bez dopadu na život & 63 & 12,8 & 12,8 \\
\hline Negatívny dopad na zamestnanie a príjem & 40 & 8,1 & 21,0 \\
\hline Obavy o zdravie (iných/blízkych) / Dopad na zdravie & 14 & 2,9 & 23,8 \\
\hline Obavy o deti: Edukácia a vol'ný čas & 41 & 8,4 & 32,2 \\
\hline Strata sociálnych kontaktov & 46 & 9,4 & 41,5 \\
\hline Negatívny vplyv na zdravie (osobné) a kvalitu života & 9 & 1,8 & 43,4 \\
\hline Hnev voči autoritám a obmedzeniam & 27 & 5,5 & 48,9 \\
\hline Psychické zdravie a reakcie (stres, strach, obavy...) & 46 & 9,4 & 58,2 \\
\hline Nedostatok vol’ného času, aktivít a oddychu & 34 & 6,9 & 65,2 \\
\hline Negatívny dopad na manželský vztłah & 7 & 1,4 & 66,6
\end{tabular}




\begin{tabular}{|c|c|c|c|}
\hline Pozitívne reakcie & 51 & 10,4 & 77,0 \\
\hline Čas pre seba (resp. pre partnera a deti) & 17 & 3,5 & 80,4 \\
\hline Zblíženie (manželov, detí a iných rodinných príslušníkov) & 27 & 5,5 & 85,9 \\
\hline $\begin{array}{l}\text { Všeobecne negatívny dopad (negatívne skúsenosti, st’aženie } \\
\text { života a žitia, chodu domácnosti a povinností) }\end{array}$ & 40 & 8,1 & 94,1 \\
\hline Nová výzva/Čelenie situácii & 29 & 5,9 & 100,0 \\
\hline Spolu & 491 & 100,0 & \\
\hline
\end{tabular}

Pozn. n - počet respondentov.

\section{Diskusia}

V predkladanom výskume sme sa zamerali na prežívanie slovenských rodín počas opatrení proti šíreniu ochorenia Covid-19. Takmer polovica respondentov $(46,9 \%)$ v našom výskume uviedla, že v ich rodinách je všetko v poriadku a neprežívajú krízu. Necelá druhá polovica rodín (45,6 \%) bola v tomto období niekedy až často v strese, no dokázali sa s ním vysporiadat'. $Z$ výsledkov teda vyplýva, že väčšina slovenských rodín neprežívala v sledovanom období závažnejšiu krízu a prípadné tažkosti dokázali zvládnut' vlastným úsilím. Toto zistenie nie je $\mathrm{v}$ súlade $\mathrm{s}$ očakávaniami založenými na výsledkoch zahraničných výskumov. Vo viacerých krajinách, napr. v Taliansku (Mazza et al., 2020), Vel'kej Británii (Mental Health Foundation, 2020) alebo v Číne (Qiu et al., 2020) bola zaznamenaná zvýšená miera preživania stresu v populácii v období prepuknutia pandémie koronavírusu. Všetky z menovaných krajín patria medzi krajiny s tažkým priebehom a rýchlym šírením ochorenia Covid-19 (World Health Organization, 2020). Slovensko v priebehu zberu dát $\mathrm{k}$ dátumu 19. 5. patrilo $\mathrm{k}$ najmenej zasiahnutým krajinám novým koronavírusom - okolo 1500 pozitívne testovaných, 237 aktívnych prípadov a 28 úmrtí (Ministerstvo zdravotníctva Slovenskej Republiky, 2020; Úrad podpredsedu vlády SR pre investície a informatizáciu, 2020). Preto vysoký podiel rodičov v našom výskume, ktorí udávajú, že ich rodiny nezažívali výraznejší stres možno vysvetlit práve dobrou epidemickou situáciou na Slovensku v sledovanom období.

Všeobecne nižšia miera pocitovanej rodinnej krízy v našej vzorke môže byt' tiež vysvetlená malým počtom respondentov, ktorých blízki alebo známi boli nakazení novým koronavírusom - iba 14 respondentov. Táto skupina respondentov mala o približne 0,7 bodu vyššie priemerné skóre prežívania krízy v rodine, v porovnaní so skupinou respondentov, ktorí neprišli do kontaktu s koronavírusom, rozdiel priemerov však nebol štatisticky významný. Pre porovnanie, respondenti výskumu z Kanady a USA, ktorí uviedli, že im bol pozitívne diagnostikovaný Covid-19 (2 \% respondentov) mali významne vyššie skóre stresu ako ludia, ktorí neboli pozitívne diagnostikovaní na Covid-19. Ale skupina respondentov, ktorí boli rizikovejší z hladiska kontaktu s nákazou Covid-19 ako zdravotníci a predavači nevykazovali vyššiu mieru stresu ako iné skupiny respondentov (Taylor et al., 2020). Zvládanie a miera pocitovaného stresu súvisiaca s pozitívnym testom na Covid-19 alebo kontakt s pozitívne testovanou osobou závisí od miery a dížky karantény, ktorá je potrebná a tiež od d’alších faktorov ako sú príznaky ochorenia, izolácia, nedostatok zásob, 
finančná tieseň či nuda a frustrácia (Brooks et al., 2020). Taylor et al. (2020) upozorňujú, že psychologický dopad Covid-19, emocionálne tažkosti, strach a panika z nového koronavírusu sú vyššie ako samostatná infikovanost' týmto vírusom.

Zaujímalo nás tiež porovnanie miery prežívania rodinnej krízy vzhl’adom na kraje Slovenskej republiky. Zistené boli štatisticky významné rozdiely medzi krajmi s najvyššou mierou prežívanej krízy, Banskobystrickým a Bratislavským krajom, a krajmi, v ktorých bola nameraná najnižšia miera rodinnej krízy, Trnavským a Trenčianskym krajom. Miera prežívaného stresu v rodinách $\mathrm{v}$ našom výskume neodzrkadluje počty pozitívne testovaných osôb v danom regióne. Banskobystrický kraj, kde sme zaznamenali vyššiu mieru prežívanej rodinnej krízy, patril medzi kraje s najnižším počtom nakazených novým koronavírusom (Ministerstvo zdravotníctva Slovenskej Republiky, 2020). Ako uvádzajú autori talianskej štúdie, faktor ako bývanie v rizikovejšej zóne nákazy nemá významný vplyv na pohodu rodičov a detí (Spinelli et al., 2020). Podobne v štúdii z Číny neboli zistené štatisticky významné rozdiely v miere úzkosti, strachu, či d’alších emócií prežívaných deṫmi v rôznych častiach krajiny s odlišnou epidemickou situáciou (Jiao et al., 2020). Nakol'ko nami zistené dáta nemožno vysvetlit epidemiologickou situáciou, dôvody by sme mohli hladat napríklad v miere dostupnosti pracovných ponúk počas pandémie, alebo tiež v schopnostiach krajských škôl zabezpečit kontinuálne vzdelávanie detí; tieto ukazovatele sa v zahraničných štúdiách ukazujú ako dôležité prediktory duševného zdravia a osobnej pohody (Andrew et al., 2020; Duffy et al., 2016). Súvislosti týchto faktorov a tiež d’alších charakteristík jednotlivých krajov s prežívaním pandémie ich obyvatelov je potrebné overit’ v d’alšom výskume.

Vnímanie dopadov pandémie koronavírusu a karanténnych opatrení na život rodín môže súvisiet’ aj s tým, akou formou rodičia v tomto období vykonávali svoju prácu. V našom výskume sme najvyššiu mieru pocitovanej rodinnej krízy zaznamenali u tých respondentov, ktorí dochádzali do práce a tých, ktorí o prácu prišli v dôsledku pandémie, no tento rozdiel bol štatisticky významný iba pri porovnaní s najmenej stresovanými rodinami, s rodičmi na rodičovskej dovolenke. Porovnatel'né zistenia reportujú aj zahraničné štúdie, ktoré poukazujú na nezamestnanost’ a dochádzanie do práce ako na stresory negatívne vplývajúce na prežívanie rodičov (CBRE, 2020; Waite et al., 2020). Vykonávanie práce formou dochádzania do kancelárie počas krízového stavu sa stalo pre rodičov jedným z najväčších stresorov (Waite et al., 2020) a naopak, práca z domu bola pozitívne hodnotená väčšinou respondentov vo viacerých krajinách Európskej únie (CBRE, 2020).

Významne vyššiu mieru preživania krízy sme zaznamenali aj v jednorodičovských rodinách v porovnaní s úplnými rodinami s dvoma rodičmi. Rodiny s jedným rodičom $\mathrm{v}$ domácnosti sa počas pandémie často ocitli okrem finančnej tiesne aj v sociálnej izolácií a bez pomoci so starostlivostou o deti (Zhou et al., 2020). Zahraniční autori takisto poukázali na jednorodičovské rodiny ako na skupinu so zvýšeným rizikom negatívnych psychologických dopadov pandémie. Zaznamenané bolo zvýšené riziko vzniku depresie u single rodičov, najmä matiek, počas pandémie koronavírusu, spôsobené najmä sociálnou izolovanost’ou, finančnými problémami a t’ažkostami zvládnut’ starostlivost’o deti bez pomoci (Alon, Doepke, Olmstead-Rumsey, \& Tertilt, 2020; Zhou et al., 2020). V rodinách 
$\mathrm{s}$ prítomnými dvoma rodičmi $\mathrm{v}$ domácnosti je predpoklad rozdelenia časti povinností medzi partnerov, čo môže znižovat' mieru pocitovaného stresu, aj ked' z americkej štúdie vyplýva, že väčšinu povinností zastáva matka (Carlson, Petts, \& Pepin, 2020).

Medzi rodinami s rôznym počtom detí nebol v našom výskume zistený štatisticky významný rozdiel v miere prežívanej krízy. European Large Families Confederation (2020) upozornila na viaceré tažkosti mnohodetných rodín počas pandémie koronavírusu, od nedostatku materiálneho zabezpečenia, komplikovanejší časový manažment v starostlivosti o deti a domácnost’ až po zabezpečenie dištančného vzdelávania pre všetky deti. V našom výskume bola zistená vyššia, no štatisticky nevýznamná, priemerná miera prežívanej rodinnej krízy u rodičov 4 a viac detí a vidíme tak potrebu d’alšieho výskumu $\mathrm{v}$ tejto problematike.

Špecifickou skupinou $\mathrm{z}$ hl'adiska dopadov pandémie koronavírusu sú tiež rodiny s det’mi so špeciálnymi výchovno-vzdelávacími potrebami. V predkladanom výskume udávali rodičia týchto detí štatisticky významne vyššiu mieru pocitovania rodinnej krízy, v porovnaní s rodičmi detí, ktoré nemali identifikované špeciálne potreby. Podobné výsledky uvádza aj anglický prieskum Co-SPACE, kde rodičia detí so špeciálnymi potrebami dosahovali vyššiu úroveň stresu v porovnaní s rodičmi detí bez špeciálnych potrieb (Waite et al., 2020). Ťažkostí zvyšujúcich stres týchto rodín môže byt’ viac, od zatvorenia vzdelávacích inštitúcií, stratu podpory a pretaženia rodiča, cez riziko regresu diet’ata zvyknutého na tím odborníkov a skomplikovania jeho zdravotných problémov, nedostatok finančných zdrojov až po problém s pochopením opatrení súvisiacich s pandémiou (Phoenix, 2020). Rodičia detí so špeciálnymi potrebami môžu pocitovat' tiež zvýšenú úzkost' a stres a tiež obavy o budúcnost’ svojho diet’ata (Asbury, Fox, Deniz, Code, \& Toseeb, 2020). UNESCO Bangkok (2020) tiež upozorňuje, že týmto rodinám je dlhodobo nedostatočne poskytovaná pomoc a podpora.

Zaradením otvorenej otázky do výskumu bolo možné bližšie preskúmat', na aké oblasti života rodín na Slovensku mala prvá vlna pandémie koronavírusu dopad. Takmer $10 \%$ rodičov v našom výskume udávalo prežívanie stresu, strachu, či obáv ( 9,4 \% odpovedí). O negatívnych dopadoch pandémie na psychické zdravie obyvatel'stva svedčia výsledky mnohých medzinárodných štúdií (Eurofound, 2020; Fitzpatrick, Harris, \& Drawye, 2020; Mazza et al, 2020; Mental Health Foundation, 2020; Qiu et al., 2020). Niektorí slovenskí rodičia zdôraznili staženie bežného života a zásah do bežných povinností $(8,1 \%)$, iným pandémia skomplikovala zamestnanie a finančný príjem (8,1 \%). Aktuálne alebo očakávané ekonomické problémy $\mathrm{z}$ dôvodu pandémie ochorenia Covid-19 patria podla zahraničných výskumov $\mathrm{k}$ jedným $\mathrm{z}$ najväčších stresorov vplývajúcich na atmosféru v rodinách (Andrew et al., 2020; Waite et al., 2020). Medzi často uvádzané dopady pandémie v našom výskume patrila tiež strata sociálnych kontaktov $(9,4 \%)$ alebo obavy o výchovu a vzdelávanie detí (8,4\%).

Napriek výzvam a vel'kým zmenám, ktoré so sebou pandémia priniesla, pre čast' respondentov (12,8 \% odpovedí) z výskumnej vzorky nemala mimoriadna situácia žiaden dopad na osobný život a takmer 20 \% respondentov dokonca opisovalo pozitívne dopady (pokojnejší život, spomalenie životného tempa, využitie času pre domáce práce, čas 
na sebarozvoj, čas pre seba a blízkych, zblíženie rodinných príslušníkov atd'.). Aj podla štúdie z USA a Kanady mnohé rodiny vnímali obdobie pandémie ako možnost’ spomalit, či obnovit kontakty s priatel'mi, viac ako polovica opýtaných rodín uviedla spokojnost' so svojím životom aj napriek obrovským zmenám (Taylor et al., 2020). Čast' respondentov sa $\mathrm{k}$ dopadu mimoriadnej situácie na osobný život nevyjadrila ( $\mathrm{n}=34)$, pričom dôvodom nezodpovedania môže byt' množstvo položiek v dotazníku aj jeho časová náročnost', či viacero otvorených otázok.

Pri interpretácii výsledkov je potrebné brat do úvahy limity predkladaného výskumu. Príležitostný výber výskumnej vzorky nezabezpečuje jej reprezentatívnost', čo sa odzrkadlilo vo vysokom zastúpení žien a vysokoškolsky vzdelaných respondentov. Vzhladom na spôsob zberu dát tiež možno predpokladat', že súčastou vzorky môžu byt' najmä rodičia so zvýšeným záujmom o problematiku edukácie prípadne psychologické témy, čo tiež môže znamenat istú mieru skreslenia. Predkladaný výskum však prináša cenné dáta o prežívaní obdobia prvej vlny pandémie koronavírusu u časti slovenských domácností, čím reaguje na aktuálnu mimoriadnu situáciu v krajine a vo svete. Upriamuje pozornost’ na rodiny so zvýšeným rizikom negatívnych psychologických dopadov pandémie, a to najmä na rodiny s det’mi so špeciálnymi výchovno-vzdelávacími potrebami a jednorodičovské rodiny. Ďalší výskum $\mathrm{v}$ tejto problematike by sa mal podrobnejšie zamerat' na prežívanie rodín priamo zasiahnutých ochorením Covid-19, prípadne mnohodetných rodín. Zaujímavou by bola tiež realizácia opakovaných meraní s ciel’om zachytit zmeny v prežívaní rodín vzhl’adom na vývoj pandemickej situácie v krajine.

\section{Záver}

Pandémia koronavírusu sa stala neočakávanou výzvou pre l’udí z celého sveta, nevynímajúc rodiny s det’mi. Väčšina slovenských rodín sa podl'a výpovedí rodičov v našom výskume vyhla prežívaniu závažnejšieho stresu či kríze a so vzniknutou neočakávanou situáciou sa vyrovnávala bez väčších tažkostí, čo môže súvisiet’ s včasným zavedením protiepidemických opatrení na Slovensku a dobrou epidemickou situáciou v krajine. Medzi rodiny, u ktorých je riziko následkov pandémie koronavírusu väčšie patria najmä rodiny s detmi so špeciálnymi potrebami a tiež jednorodičovské rodiny. Aj podl’a výsledkov nášho výskumu tieto rodiny prežívali krízu v intenzívnejšej miere a preto by mali figurovat na popredných priečkach poskytovania intervencie a odbornej pomoci. Dôležitost’ takéhoto kroku potvrdzujú aj zistenia, že vnímaný stres rodiča počas pandémie Covid-19 zvyšuje aj vnímaný stres samotného dietata, čo môže viest’ k zhoršeniu emocionálneho stavu diet’ata a tiež ovplyvnit’ jeho správanie (Spinelli et al., 2020). Následkom zvýšeného pocitovaného stresu rodiča, narušeného emocionálneho blaha diet’ata a behaviorálnych problémov môže byt aj zvýšené riziko vzniku partnerských problémov a domáceho násilia (Chung et al., 2020). Pandémia a reštrikčné opatrenia s ňou súvisiace nám opät pripomenuli potreby zranitel'nejších členov našej spoločnosti a nutnost’ vytvorenia podporných sietí nielen pre deti, ale aj ich rodičov a rodinu ako celok. 


\section{Referencie}

Alon, T. M., Doepke, M., Olmstead-Rumsey, J., \& Tertilt, M. (2020). The Impact of COVID-19 on Gender Equality. Dostupné z https://www.nber.org/papers/w26947 https://doi.org 10.3386/w26947

Andrew, A., Cattan, S., Dias, M., Farquharson, Ch., Kraftman, L., Krutikova, S., Phimister, A., \& Sevilla, A. (2020). How are mothers and fathers balancing work and family under lockdown? The Institute for Fiscal Studies. 31 p. ISBN 978-1-912805-80-8 Dostupné z https://mk0nuffieldfounpg9ee.kinstacdn.com/wp-content/uploads/2020/04/BN290-Mothers-and-fathers-balancing-work-and-life-under-lockdown.pdf

Asbury, K., Fox, L., Deniz, E., Code, A., \& Toseeb, U. (2020). How is Covid-19 affecting the mental health of children with special educational needs and disabilities and their families? Dostupné $\mathrm{z}$ https://doi. org/10.31234/osf.io/sevyd

Beland, L. P., Brodeur, A., Haddad, J., \& Mikola, D. (2020). COVID-19, Family Stress and Domestic Violence: Remote Work, Isolation and Bargaining Power. Dostupné $\mathrm{z}$ http://ftp.iza.org/dp13332.pdf

Biroli, P., Bosworth, S., Della Giusta, M., Di Girolamo, A., Jaworska, S., \& Vollen, J. (2020). Family Life in Lockdown. Dostupné $\mathrm{z}$ http://ftp.iza.org/dp13398.pdf

Blustein, D. L. (2019). The importance of work in an age of uncertainty: The eroding work experience in America. NY: Oxford University Press.

Brooks, S., Webster, R., Smith, L., Woodland, L., Wessely, S., Greenberg, N., \& Rubin, G. (2020). The psychological impact of quarantine and how to reduce it: rapid review of the evidence. Dostupné $\mathrm{z}$ https:// www.thelancet.com/journals/lancet/article/PIIS0140-6736(20)30460-8/fulltext,https://doi.org/ 10.1016/S0140-6736(20)30460-8

Carlson, L., Petts, R., Pepin, J. (2020). US couples' divisions of housework and childcare during Covid-19 pandemic. Dostupné $\mathrm{z}$ https://doi.org/10.31235/osf.io/jy8fn

CBRE. (2020). CBRE CEE \& SEE Work from Home Survey Special Report. Dostupné z https://www.cbre. sk/en/research-and-reports/CBRE_CEE-and-SEE_Work-from-Home-Survey-Special-Report

Chung, G., Chan, V., Lanier, P., \& Wong, P. (2020). Associations Between Work-Family Balance, Parenting Stress, and Marital Conflicts During COVID-19 Pandemic in Singapore. Dostupné z https://www.researchgate.net/publication/342447541_Associations_Between_Work-Family_Balance_Parenting Stress_and_Marital_Conflicts_During_COVID-19_Pandemic_in_Singaporehttps://doi.org/10.31219/ osf.io/nz9s8

Dalton, L., Rapa, E., \& Stein, A. (2020). Protecting the psychological health of children through effective communication about COVID-19. Dostupné z https://www.thelancet.com/pdfs/journals/lanchi/ PIIS2352-4642(20)30097-3.pdf https://doi.org/10.1016/S2352-4642(20)30097-3

Devine, B.F., \& Foley, N. (2020). Women and the Economy. Dostupné z https://commonslibrary.parliament.uk/research-briefings/sn06838/

Duffy, R.D., Blustein, D.L., Diemer, M.A., \& Autin, K.L. (2016). The psychology of working theory. Journal of Counseling Psychology, 63(2), 127-148. https://doi.org/ 10.1037/cou0000140

Elliott, A.C., \& Woodward, W.A. (2007). Statistical analysis quick reference guidebook with SPSS examples. London: Sage Publications.

Eurofound. (2020) Living, working and COVID-19. First findings - April 2020. Dostupné z https://www. eurofound.europa.eu/sites/default/files/ef_publication/field_ef_document/ef20058en.pdf

European Large Families Confederation. (2020). ELFAC statement on large families in Europe and COVID-19 emergency. Dostupné $\mathrm{z}$ https://www.elfac.org/elfac-statement-on-the-occasion-of-the-covid-19-pandemic-in-europe-and-large-families/

Fitzpatrick, K. M., Harris, C., \& Drawve, G. (2020). Fear of COVID-19 and the Mental Health Consequences in America. Dostupné z https:/fulbright.uark.edu/departments/sociology/research-centers/ community-family-institute/_resources/community-and-family-institute/2020-fear-of-covid19-and-the-mental-health-consequences-in-america.pdf 
Holmes, A. E., O'Connor, R., Perry, H., Tracey, I., Wessely, S., Arseneault, L... Bullmore, E. (2020). Multidisciplinary research priorities for the COVID-19 pandemic: a call for action for mental health science. Dostupné z https://www.thelancet.com/journals/lanpsy/article/PIIS2215-0366(20)30168-1/fulltext https://doi.org/10.1016/S2215-0366(20)30168-1

Jiao, W., Wang, L., Liu, J., Fang, S., Jiao, F., Pettoello-Mantovani, M., \& Somekh, E. (2020). Behavioral and Emotional Disorders in Children during the COVID-19 Epidemic. Dostupné $\mathrm{z}$ https://www.ncbi. nlm.nih.gov/pmc/articles/PMC7127630/ https://doi.org/10.1016/j.jpeds.2020.03.013

Karpman, M., Zuckerman, S., \& Peterson, G. (2020). Adults in Families Losing Jobs during the Pandemic Also Lost Employer Sponsored Health Insurance. Dostupné $\mathrm{z}$ https://www.urban.org/sites/default/ files/publication/102533/adults-in-families-losing-jobs-in-the-pandemic-also-lost-employer-sponso_l.pdf

Mazza, C., Ricci, E., Biondi, S., Colasanti, M., Ferracuti, S., Napoli, Ch., \& Roma, P. (2020). A Nationwide Survey of Psychological Distress among Italian People during the COVID-19 Pandemic: Immediate Psychological Responses and Associated Factors. Dostupné z https://www.ncbi.nlm.nih.gov/pmc/ articles/PMC7246819/ https://doi.org/10.3390/ijerph17093165

Mental Health Foundation. (2020). The COVID-19 Pandemic, Financial Inequality and Mental Health. Dostupné z https://www.mentalhealth.org.uk/our-work/research/coronavirus-mental-health-pandemic/covid-19-inequality-briefing

Ministerstvo zdravotníctva Slovenskej Republiky. (2020).COVID-19:Pribudol jeden nový prípad, dalších 39 pacientov sa vyliečilo. Dostupné $\mathrm{z}$ https://www.health.gov.sk/Clanok?covid-19-20-05-2020-vysledky

Národná Banka Slovenska. (2020). Miera evidovanej nezamestnanosti: $V$ apríli nezamestnanost' vzrástla historicky najvy̌šsím tempom. Dostupné z https://www.nbs.sk/_img/Documents/_komentare/2020/1194_rk_nez_20200521.pdf

Nobles, J., Martin, F., Dawson, S., Moran, P., \& Savovic, J. (2020). The potential impact of COVID-19 on mental health outcomes and the implications for service solutions. National Institute for Heltah Research, Univeristy of Bristol. Dostupné z https://arc-w.nihr.ac.uk/Wordpress/wp-content/ uploads/2020/04/COVID-19-Rapid-Review-COVID-and-Mental-Health-FINAL.pdf

Phoenix, M. (2020). Children with disabilities face health risks, disruption and marginalization under coronavirus. Dostupné $\mathrm{z}$ https://theconversation.com/children-with-disabilities-face-health-risks-disruption-and-marginalization-under-coronavirus-137115

Prognostický ústav Slovenskej akadémie vied; INFOSTAT - Výskumné demografické centrum; Katedra humánnej geografie a demografie Prírodovedeckej fakulty Univerzity Komenského (2014).Prognóza vývoja rodín a domácnostína Slovensku do roku 2030. Bratislava: Prognostický ústav Slovenskej akadémie vied. Dostupné z http://www.infostat.sk/vdc/pdf/Prognoza_rodin.pdf

Qiu, J., Shen, B., Zhao, M., Wang, Z., Xie, B., \& Xu, Y. (2020). A nationwide survey of psychological distress among Chinese people in the COVID-19 epidemic: implications and policy recommendations. Dostupné z https://www.ncbi.nlm.nih.gov/pmc/articles/PMC7061893/http://dx.doi.org/10.1136/ gpsych-2020-100213

Spinelli, M., Lionetti, F., Pastore, M., \& Fasolo, M. (2020). Parents' Stress and Children's Psychological Problems in Families Facing the COVID-19 Outbreak in Italy. Dostupné $\mathrm{z}$ https://www.frontiersin. org/articles/10.3389/fpsyg.2020.01713/full https://doi.org/10.3389/fpsyg.2020.01713

Taylor, S., Landry, C.A., Paluszek, M., Fergus, T., McKay, D., \& Asmundson, G. (2020). COVID stress syndrome: Concept, structure, and correlates. Dostupné z https://onlinelibrary.wiley.com/doi/ full/10.1002/da.23071 https://doi.org/10.1002/da.23071

UNESCO Bangkok. Empowering students with disabilities during the COVID-19 crisis. Dostupné $\mathrm{z}$ https:// shorturl.at/elEIQ

Úrad podpredsedu vlády SR pre investície a informatizáciu. (2020). Koronavírus na Slovensku $v$ čislach. Dostupné z https://korona.gov.sk/koronavirus-na-slovensku-v-cislach/ 
Waite, P., Patalay, P., Moltrecht, B., McElroy, E., \& Creswell, C. (2020). Co-SPACE study. Report 02: Covid-19 worries, parent/carer stress and support needs, by child special educational needs and parent/ carer work status. Dostupné $\mathrm{z}$ https://emergingminds.org.uk/wp-content/uploads/2020/05/ Co-SPACE-report-02_03-05-20.pdf

Weiss, J. A., \& Lunsky, Y. (2011). The Brief Family Distress Scale: A Measure of Crisis in Caregivers of Individuals with Autism Spectrum Disorders. Journal of Child and Family Studies, 20, 521-528. https://doi.org/10.1007/s10826-010-9419-y

World Health Organization. (2020). Coronavirus Disease (COVID-19) Dashboard. Dostupné z https:// covid19.who.int/?gclid=EAIaIQobChMIlv60wdzR6gIVC9iyCh12YQFoEAAYASAAEgKkKvD_ BwE

Zhou, M., Hertog, E., Kolpashnikova, K., \& Kan, M. (2020). Gender inequalities: Changes in income, time use and well-being before and during the UK COVID-19 lockdown. Dostupné $\mathrm{z}$ https://doi. org/10.31235/osf.io/u8ytc

Korespondenčný autor: Robert Tomšik, Výskumný ústav detskej psychológie a patopsychológie VúDPaP, Cyprichova 42, 83105 Bratislava, Slovenská republika. Email: robert.tomsik@vudpap.sk

Rajčániová, E., Ferenčíková, P., Tomšik, R., \& Kopányiová, A. (2020). Prežívanie krízy $\checkmark$ rodinách počas pandémie Covid-19 na Slovensku. Psychologie a její kontexty, 17(2), 35-53. https://doi.org/10.15452/PsyX.2020.11.0009 